\title{
The Effect of Inflation and Private Investment on Open Unemployment in North Maluku (Partial Adjudication Model (PAM) Approach)
}

\author{
Nonce Hasan Muammil Sun'an \\ Faculty of Economics, Khairun University, Ternate, Indonesia
}

\begin{abstract}
The unemployment problem is very complex and an important issue. It can relate to several indicators. Economic indicators to affect the unemployment level include economic growth, inflation level, private investment and the wages. This study objective is to analyze the effect of private investment and inflation on unemployment level in North Maluku Province. The model is analyzed by stationarity test, cointegration approach, and partial adjustment model (PAM). The results showed that inflation level had a significant and positive effect on unemployment level in North Maluku Province. Private investment had a significant and negative effect on unemployment. Then all research variables (inflation, private investment, and unemployment) had a balance relationship in long run.
\end{abstract}

Keywords: Inflation, Private Investment, Open Unemployment, Partial Adjustment Models.

DOI: $10.7176 / \mathrm{JESD} / 10-12-07$

Publication date:June $30^{\text {th }} 2019$

\section{INTRODUCTION}

Unemployment is defined as someone belong to workforce and actively looking for work at a certain wage level, but does not get the desired job. Large unemployment in a region becomes a multidimensional problem economy. Unemployment also has a close relationship with social and educational fields. Educated and non educated people have unemployment status (Sukirno, 2008).

The relationship between inflation and unemployment began to attract the economists attention in late 1950s, when AW Phillips published his article in Economical journal entitled The Relationship between Unemployment and Rate of Change of Money Wage Rate in United Kingdom published. He showed a negative relationship between the wage level increase and unemployment level (which is known as the Phillips curve). Phillips's research used data on wages change and unemployment in United Kingdom during the years 1861-1913 to illustrate how the relationship between inflation and unemployment level based on assumption that inflation was a reflection of an increase in aggregate demand. The demand theory stated that, if the demand rises then the price will rise. With high prices (inflation), to fulfil the demand, producers increase their production capacity by increasing labor (labor is the only input that can increase output). As a result, there is an increase in labor demand so that unemployment level decreases (Arnson, 2002).

Investment is another determinant of economic growth level. It encourages a significant increase in output and also increases input demand that will increase employment opportunities and public welfare increase as a consequence of income received by community (Makmun and Yaksin, 2003). Investment causes an increase in production of goods which also affects the labor demand. It increases employment to reduce unemployment. Investment is very important for economic development activities. Investments can be done by private sector, government or cooperation between the government and private sector. Investment is a way that can be done by government to increase economic growth and in long term can raise the living standards of the people (Mankiw, 2003). The investment increase will boost trade volume and production volume, which in turn will expand productive employment opportunities and capita income increase while at same time increase the community welfare.

Capital stock or investment is one important factor to determine level of national income. Investment activities allow a society to continuously improve economic activities and employment opportunities, national income increase and prosperity levels (Sukirno, 2000: 367). The investments will encourage the creation of new capital goods so that it will absorb new production factors, namely creating new jobs or employment opportunities to absorb labor which in turn will decrease the unemployment (Prasojo, 2009),

\section{Problems Formulation}

Based on above description of introduction, the examined problems are below.

1. Does the inflation level affect on unemployment level in North Maluku Province?

2. Does private investment affect on unemployment level in North Maluku Province?

3. Does the inflation level and investment affect on the short-term and long-term unemployment level in North Maluku Province? 


\section{Research purposes}

Based on above research problems, these study purposes are below.

1. Analyzing the effect of inflation level on unemployment level in North Maluku Province.

2. Analyzing the effect of private investment on unemployment level in North Maluku Province.

3. Analyzing the effect of inflation level and investment on short and long-term unemployment level in North Maluku Province.

\section{LITERATURE REVIEW}

\section{Theoretical basis}

Understanding the Unemployment

Unemployment is a measure if a person does not have a job but they are actively tries in last four weeks to find a job (Kaufman and Hotchkiss, 1999). Unemployment is a condition where a person belongs to workforce who wants to get a job but they have not been able to get the job (Sukirno, 1994). Unemployment can occur due to an imbalance in labor market. This shows that labor offer exceeds the labor demand. The causes basis of unemployment is imbalance between the factors to cause unemployment in general (Sugiyanto, 2006), among others:

1. Low level of education

2. Low skills and experience possessed

3. Not comparable between work and land employment

4. Other factors (e.g. picky work)

Samuelson (1992) defined unemployment as a person who does not work but actively seeks employment or is being called back to work in his company. In other words, a person is said to be unemployed if he does not work and (a) tries to find a job for past four weeks, (b) has just been laid off from work and is waiting to be called back or (c) is preparing a job application for next month. In addition there is the term forced unemployment and voluntary unemployment. The notion of voluntary unemployment is those who do not want to work at prevailing wage level in labor market. This group is people who do not want to work because of low wages or other factors such as high levels of education that tend to be unemployed rather than working with low wages. While forced unemployed those who are not absorbed in economic activities due to limited employment opportunities.

\section{Type of Unemployment}

The type unemployment can be grouped below.

1. Open unemployment, this unemployment arises as a result of job opportunity growth lower than the workforce growth. It is happened in an economy where more and more workers do not get jobs. These workers in long term are not included in economic activities; they are unemployed in a real and full time.

2. Quasi unemployment, this unemployment is occurred because workers work below normal working hours, usually around 36 hours per week. Those who work less than working hours are grouped in groups of quasi unemployment.

3. Covert unemployment (disguised unemployment); this unemployment arises when number of workers in an economic activity is more than the actual needs to produce efficient production. Theoretically, the unemployment production arises because Marginal Productivity of company has been below zero, but companies or organizations continue to increase labor because of various considerations.

4. Seasonal Unemployment, this collusion occurs a lot in agricultural sector, in rainy season fishermen and rubber tapers cannot work, they are forced to unemployed waiting for rainy season to finish. This also happens to farmers during the dry season which causes farmers to be unable to work because the land is dry and there is no water. During this dry season farmers are forced to be unemployed.

\section{The Relationship between Inflation Levels and Unemployment}

The inflation level has positive or negative relationship unemployment. If the inflation level calculated is inflation that occurs in prices in general, then the high rate of inflation that occurs will result in an increase in interest rate (loan). Therefore, a high interest rate will reduce investment to develop productive sectors. This will affect the high unemployment because of low employment opportunities as a result of low investment (Sukirno, 1994). With tendency that inflation level and unemployment increase shows a difference with Philips curve where there is a trade-off between low inflation and low unemployment (Nopirin, 2000).

First, Phillips curve provides a rough picture of inflation process causality. The low level of unemployment is considered to have a relationship with labor market tightness and high level of income and demand from consumers. The Phillips curve also makes a trade off between unemployment and inflation. If the desired inflation level is low, there will be very high unemployment. Conversely, if the inflation level is desired high, there will be a relatively low unemployment level (Dernburg and Karyaman Muchtar, 1992).

The Phillips curve illustrates the relationship between inflation level and unemployment level based on 
assumption that inflation is a mirror to increase in aggregate demand. Higher aggregate demand will increase demand, and then prices will rise as well. With high prices (inflation) to fulfil the demand, producers increase their production capacity by increasing labor (labor is the only input that can increase output). As a result of increase in labor demand, prices increase (inflation) decrease the unemployment.

\section{Relationship between Investment and Unemployment}

Investment is the key word to determine the economic growth level. It will encourage a significant increase in output and automatically increase input demand, in turn it will increase employment opportunities and public welfare as a consequence of higher income received by community (Makmun and Yasin, 2003). Investment is the resources mobility to create or increase production capacity or future income. Investment has two main objectives, namely replacing part of damaged supply capital and additional provision of existing capital. Descriptions of regional development can not be separated from development of distribution and allocation of investment between regions.

It is necessary to separate the investments types made by private sector and government, given the location determining factors of two investments types are not always same. Generally government still has to pay attention to several factors, such as the development of a certain area for political and strategic reasons. For example, border areas and regions have special history and characteristics, so that special attention is needed in investment policy. However, the investments types from government and private sector ultimately can increase employment opportunities and contribute to overcome economic and social problems such as poverty, unemployment and others.

The investment size in community will greatly affect the employment size opportunities created in community. The investment will increase production activities to open new employment opportunities. The new employment opportunities will cause unemployment reduction. This means that investment level rises increase can decrease the unemployment level. Adversely, lower investment falls will increase the unemployment level. Investment increase in capital intensive does not affect the labor market. Narrow employment is due to capital scarcity to invest. This is a result of financial crisis that devastated the national economy. Many entrepreneurs were bankrupt because bad bank debts. Many workers or factory workers were lay off by company in order to reduce the cost used to pay the salaries. This triggers unemployment boom to surge unemployment in a relatively short time.

Harrod-Domar (Mulyadi, 2000) said that investment not only creates demand, but also increases production capacity. Labor, as one factors of production, will automatically increase. The dynamics of investment affect the growth level of economy, reflecting the rampant sluggishness of development. Every country tries to create a climate that can stimulate investment, especially private investment to create employment opportunities and decrease the unemployment.

\section{Previous research}

The relationship between inflation and unemployment level has been done by researchers in various countries, using data panels and time series and different methods. In his article entitled "Testing of Phillips Curve", Arnson (2002) conducted a study to test Philips curve theory in Japan, Germany and United States, using a simple linear regression model. The data series used is 1960-2000. Japan and Germany showed a significant negative relationship between unemployment and inflation, while United States shows a positive relationship or contradict to Philips curve theory.

Atkeson and Ohanian (2001 in Lansing, 2002) examined whether the Phillips Curve can be used to estimate inflation data, using two types of short-run data, namely 1960-1983 and 1984-2002. Their results showed that short run data cannot be used to predict inflation. The relationship between inflation and unemployment only occurs in short term, and is not proven in long run. The regression results using 1960-1983 data indicate a significant negative relationship between inflation and unemployment level, but for 1984-2002 periods, regression coefficient was close to zero, it means there is no relationship between the current unemployment level and inflation future level. Therefore, trade-off between inflation and unemployment level in short term cannot be used to predict the nominal value of inflation level but may only be used to predict the direction of future changes in inflation.

John Dinarno and Mark P. Moore (1999) examine the relations between inflation level (through the GDP Deflator) and unemployment level in nine OECD countries, including: Belgium, Canada, France, Germany, Italy, Japan, Netherlands, United Kingdom and United States. This research uses a data panel with OLS (Ordinary Least Square) calculation model. The data used are cross section on inflation level (using CPI, quarter), unemployment level and interest rate (to measure expectations of future inflation). This study there is a positive relationship between inflation level through GDP Deflator and unemployment level. Higher inflation level in a country will increase the unemployment level.

Amri Amir (2010) examined the effect of inflation and economic growth on unemployment in Indonesia. This study also refers to Phillips curve analysis and uses multiple linear regression analysis. The research showed the unemployment level affect on economic growth. If economic growth increases by 1 percent, unemployment 
will decline by around 0.46 percent. Therefore, Phillips curve to connect inflation with unemployment level in Indonesia is not appropriate to be used as a policy to reduce the unemployment level. The results of statistical analysis testing the effect of inflation on unemployment during the period 1980 - 2005 found inflation has no significant effect on unemployment level.

Rum (2007) analyzed the determinants of Indonesian Open Unemployment for 1980-2007 periods. The results showed that economic growth level has a positive and significant effect on Open Unemployment in Indonesia for 1980-2006 periods. This means that higher economic growth level increase the open unemployment in Indonesia. Second, Government Expenditures have a negative and significant effect on Open Unemployment in Indonesia for 1980-2006 periods. This means that higher government expenditure decrease the unemployment. Third, Inflation has no significant effect on open unemployment in Indonesia for 1980-2006 periods, but in a negative direction. This means that higher the inflation level decrease open unemployment level. Fourth, Economic Growth Rate, Government Expenditures and Inflation simultaneously have significant effect on Open Unemployment in Indonesia for 1980-2006 periods.

\section{Framework}

The inflation level can have a positive or negative relationship with large unemployment. The inflation increase will lead to unemployment increase. The inflation increase will reduce the rate and investment. As a result the unemployment increases will decrease the employment opportunities. Phillips theory said that inflation has a positive effect on unemployment. This is based on assumption that inflation is a reflection of aggregate demand increase. Aggregate demand increase, based on theory of demand, will increase prices. High prices (inflation) makes producers increase their production capacity by increasing labor (labor is the only input that can increase output). As a result of higher labor demand because of higher prices (inflation) can decreases the unemployment.

Harrod-Domar's theory is the direct development of short-term macro Keynes theory into a long-term macro theory. The main aspects developed by Keynesian theory are the role of investment (I) in long term. In Keynesian theory, investment expenditure (I) affects aggregate demand (Z) but does not affect aggregate supply (S). Harrod - Domar examined the effect of investment in a longer time perspective. According to these two economists, investment expenditure (I) does not only affect (through a multiplier process) on aggregate demand (Z), but also on aggregate supply (S) through the effect on production capacity to reduce unemployment (Boediono, 1999), as shown in figure 1.

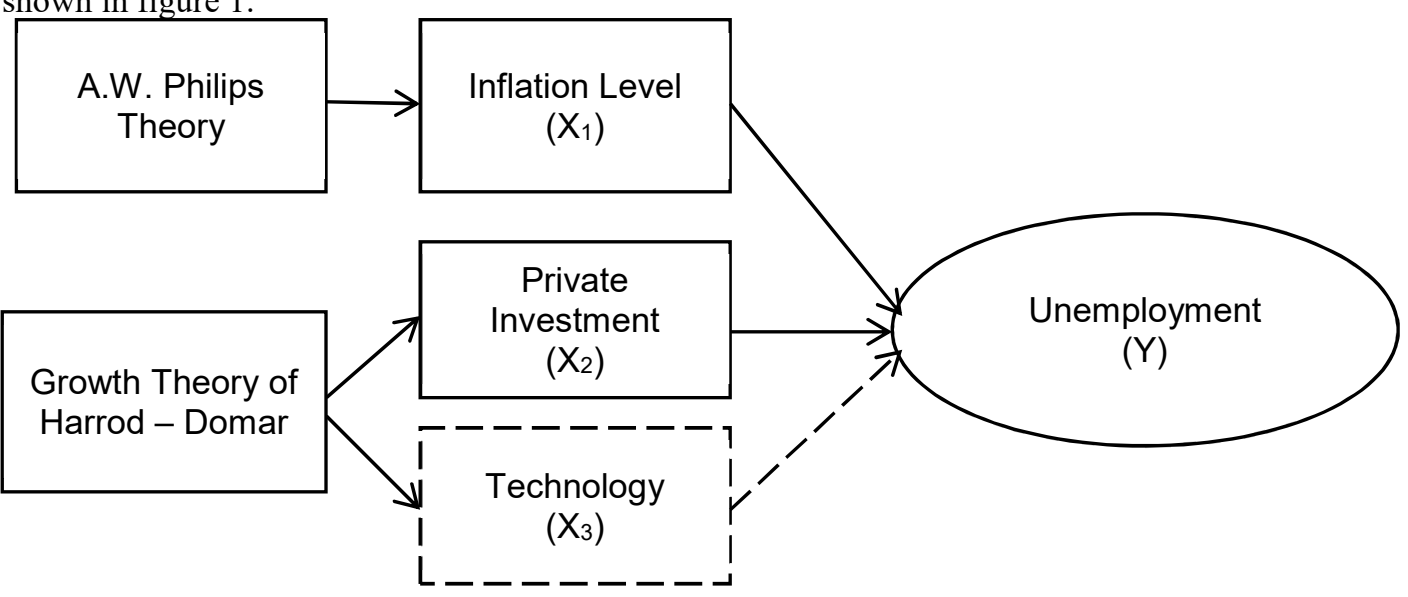

Description:

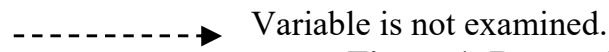

Figure 1. Research Model

The investment level in an area will certainly affect on unemployment in the area. This is due to investment, there will be an expansion of business, both the capital and labor usage will increase. Therefore, investment is expected to reduce the unemployment.

This study will only limit its analysis to the effect of inflation and private investment on unemployment in North Maluku Province by using a partial adjustment model (Partial Adjudication Model, PAM) to determine the effect of short and long term between research variables.

\section{Research Hypothesis}

Theoretical description and research framework produces hypotheses below.

H1: The inflation level has a negative effect on unemployment level in North Maluku Province.

H2: Private investment has a negative effect on unemployment level in North Maluku Province

H3: The inflation level and private investment affect on the short-term and long-term unemployment level in North Maluku Province. 


\section{RESEARCH METHODS}

Types and Data Sources

This study examines the relationship between macroeconomic variables based on economic theory then described in econometric model. Econometric model with data support then processed with statistical methods to obtain parameter value of economic relations from these economic variables. This study uses secondary data with time series data type. Data is taken from agencies related to research problems, including the Central Bureau of Statistics (BPS), Bank Indonesia Reports (SEKI), and other sources. The collected data includes:

1. Unemployment level

2. Private investment

3. Inflation level

\section{Operational Definition}

Research variables are the research subject or point attention of a study (Arikunto, 2006). The variables used in this study include:

1. Inflation level (X1) is a tendency to increase the price of goods and services continuously. This indicates too much money to get limited goods, and expressed as a percentage.

2. Private investment (X2) is an investment made by a private party or an entrepreneur with aim to get profit in one year and expressed in rupiah.

3. The unemployment level (Y) is the unemployment people, including the workforce but not doing work or looking for work. The unemployment variable is the number of open unemployment in Indonesia, using data from BPS, namely data on people aged ( 15 years above) who are looking for work, preparing for business, not looking for work, not starting work. Data is annual, from 2010 to 2015 and unit analysis is person.

\section{Data analysis method}

The analysis tool to process time series data is a dynamic model. There are two important things that need to be considered, namely the reduction and statistical issues of dynamic model (Insukindro, 1990).

\section{Stationarity Test (Unit root test)}

It test whether a data time series contains elements of trend or not done by unit root test. The unit root test or ADF (Augmented Dickey-Fuller) is also important to detect the data stationary. This test contains a regression from first differential data of time series of lag variables, lagged difference terms, constants, and trend variables.

There are several stationarity test methods IN unit root tests. The unit root test developed by Dickey-Fuller is a widely applied test. The test is called the DF test (Dickey-Fuller) and ADF (Augmented Dickey-Fuller) test. The $\mathrm{DF}$ and $\mathrm{ADF}$ test formulations are as follows:

$$
\begin{gathered}
\mathrm{DX}_{\mathrm{t}}=\mathrm{a}_{0}+\mathrm{a}_{1} \mathrm{BX}_{\mathrm{t}}+\sum_{\mathrm{t}=1} \mathrm{a}_{2} \mathrm{~B}^{\mathrm{i}} \mathrm{DX} \mathrm{X}_{\mathrm{t}} \\
\mathrm{k} \\
\mathrm{DX}_{\mathrm{t}}=\mathrm{b}_{0}+\mathrm{b}_{1} \mathrm{BX}_{\mathrm{t}}+\sum_{\mathrm{t}} \mathrm{b}_{2} \mathrm{~B}^{\mathrm{i}} \mathrm{DX} \mathrm{X}_{\mathrm{t}}
\end{gathered}
$$

Where:

$\mathrm{X}=$ observed variable

$\mathrm{B}=$ operator lag

$\mathrm{DX}_{\mathrm{t}}=\mathrm{X}_{\mathrm{t}}-\mathrm{X}_{\mathrm{t}-1}$

$\mathrm{BX}_{\mathrm{t}}=\mathrm{X}_{\mathrm{t}-1}$

$\mathrm{T}=$ time trend

Procedure to determine the data stationary IS is comparison the ADF statistical value and the critical value. If the absolute value of ADF statistic is greater than the critical value, then the observed data shows are stationary and if otherwise the data is not stationary. If the unit root test concludes that data is not stationary, then the next step is needed to test the degree of integration (Gujarati, 1995; Insukindro, 1993).

\section{Partial Adjustment Model (PAM)}

Other rationalization of Koyck model is the Partial adjustment model (PAM). The flexible accelerator model from economic theory assumes the existence of optimal balance in long run (Widarjono; 2016). Suppose the desired unemployment association $(\mathrm{U} * \mathrm{t})$ with inflation $(\mathrm{Rt})$ and private investment $(\mathrm{It})$, the formulation is written below

$$
\mathrm{U}^{*}{ }_{\mathrm{t}}=\beta_{0}+\beta_{1} \mathrm{P}_{\mathrm{t}}+\beta_{1} \mathrm{I}_{\mathrm{t}}+\varepsilon_{\mathrm{t}}
$$

Because the desired unemployment level cannot be observed directly, Nerlove postulates the following hypothesis, known as the partial adjustment hypothesis, or stock adjustment:

$$
\mathrm{U}_{\mathrm{t}}-\mathrm{U}_{\mathrm{t}-1}=\delta\left(\mathrm{U}_{\mathrm{t}}^{*}-\mathrm{U}_{\mathrm{t}-1}\right)
$$

Where $0<\delta<1$ is called the adjustment coefficient; $U_{t}-U_{t-1}$ is the actual change from unemployment; and $U^{*}{ }_{t}-$ 
$\mathrm{U}_{\mathrm{t}-1}$ is the desired change in unemployment.

Equation (3.2) states that change in actual unemployment in period $t$ is $\delta$ of desired change in unemployment in that period. If $\delta=1$, actual unemployment level equals to desired unemployment level. In other words, actual unemployment adjusts directly to desired unemployment at the same time. If $\delta=0$ then there is no change in unemployment because the actual unemployment period $t$ equals to unemployment of previous period $t-1$. In general, value will be at values of 0 and 1 because the unemployment adjustment to equilibrium level is not perfect. Therefore this adjustment model is called Partial Adjustment Model.

Adjustment mechanisms (3.2) can be written alternatively as follows:

$$
\mathrm{U}_{\mathrm{t}}=\delta \mathrm{U}_{\mathrm{t}}^{*}+(1-\delta) \mathrm{U}_{\mathrm{t}-1}
$$

The unemployment level in period $t$ is the weighted average of desired unemployment level at that time and unemployment level in previous time period, with $\delta(1-\delta)$ as its weight. Now by substituting (3.1) to (3.3), it creates

Where vt $=\delta$ et

$$
\begin{aligned}
\mathrm{U}_{\mathrm{t}} & =\delta\left(\beta_{0}+\beta_{1} \mathrm{P}_{\mathrm{t}}+\beta_{2} \mathrm{I}_{\mathrm{t}}+e_{\mathrm{t}}\right)+(1-\delta) \mathrm{U}_{\mathrm{t}-1} \\
& =\delta \beta_{0}+\delta \beta_{1} \mathrm{P}_{\mathrm{t}}+\delta \beta_{1} \mathrm{I}_{\mathrm{t}}+(1-\delta) \mathrm{U}_{\mathrm{t}-1}+\delta v_{\mathrm{t}}
\end{aligned}
$$

Equation (3.1) is a model of long-term unemployment or unemployment balance, while the equation in equation (3.4) is a model of unemployment in short term.

\section{RESEARCH RESULTS AND DISCUSSION \\ Interpretation of Test Results \\ Data Stationarity Test (Unit root test)}

Regression with non-stationary time series data is most likely to produce spurious regression. Direct regression is occurred if the determination coefficient is high enough but the relationship between the independent variable and dependent variable has no meaning because the relationship between the two time series data only shows trend. The high determination coefficient is caused by trend not relationship between the two (Widarjono, 2005).

Procedure to determine the stationary data is to compare the ADF statistical value with its critical value. If the absolute value of ADF statistic is greater than the critical value, then the observed data shows stationary and if otherwise the data is not stationary. If the unit root test shows the data is not stationary, then the next step is needed to test the degree of integration (Gujarati, 1995; Insukindro, 1993).

Table 1. Data Stationarity Test Results

\begin{tabular}{|l|c|c|c|c|}
\hline \multirow{3}{*}{ Variables } & \multicolumn{4}{|c|}{ Unit Square Test } \\
\cline { 2 - 5 } & \multicolumn{3}{|c|}{ Level } & 1st-difference \\
\cline { 2 - 5 } & ADF & Prob & $-4.7497 *$ & 0.0053 \\
\hline INF & 2.3826 & 0.3779 & $-4.4222^{*}$ & 0.0222 \\
\hline INV & 2.0246 & 0.5580 & $-4.0029 *$ & 0.0014 \\
\hline TPT & 3.2185 & 0.1055 & Prob \\
\hline Description: * significant $1 \%, 5 \%$, dan $10 \%$.
\end{tabular}

The test results in table above show that all variables turned out to be stationary in $1^{\text {st }}$-difference or in first integrated data, I (1). Therefore, the next testing step can be done. All time series data in this study (INF, INV, and TPT) have the same average value, variance, and covariance at each lag and remain same at all times. In other words, it is constant and does not change all the time (Widarjono, 2016). The next important implication is the results of analysis of this study will avoid the possibility of spurious regression.

\section{Regression Analysis Results for Unemployment level}

A. Partial Testing of Regression Coefficients (t Test)

The partial regression coefficient test examines the relationship between researched variables separately. The partial effect of independent variables is indicated by magnitude of each statistic $t$ value. Table 2 shows that partially only the inflation variable affects the unemployment level in North Maluku Province. The private investment variable does not have a significant effect on unemployment level. This is indicated by significant magnitude of t-statistic value at $\alpha 5 \%$ or the probability value below 0.05 .

\section{B. Simultaneous Testing of Regression Coefficients (Test F)}

Simultaneous testing of regression coefficient examines the simultaneous effect of independent variables on dependent variable. It is indicated by magnitude of $F$ statistic value. Table 2 shows that simultaneously the independent variables (inflation and private investment) have a significant effect on dependent variable (unemployment level). The simultaneous effect of independent variables is significant at $\alpha 5 \%$, . It the magnitude of F-statistic value which is greater than the F-Table value. The changes in independent variable simultaneously change unemployment level. 
Table 2. Linear Regression Test Results

\begin{tabular}{|c|c|c|c|c|}
\hline \multicolumn{3}{|c|}{ Dependent Variable: D(TPT) } & & \\
\hline \multicolumn{3}{|c|}{ Method: Least Squares } & & \\
\hline \multicolumn{3}{|c|}{ Date: $03 / 18 / 18$ Time: $11: 07$} & & \\
\hline \multicolumn{5}{|c|}{ Sample (adjusted): 2011Q2 2016Q4 } \\
\hline \multicolumn{4}{|c|}{ Included observations: 23 after adjustments } & \\
\hline Variable & Coefficient & Std. Error & t-Statistic & Prob. \\
\hline $\mathrm{C}$ & 0.083989 & 0.397969 & 0.211043 & 0.8350 \\
\hline $\mathrm{D}(\mathrm{INF})$ & 1.353270 & 0.504306 & 2.683427 & 0.0143 \\
\hline D(INV) & -0.006109 & 0.010240 & -0.596549 & 0.5575 \\
\hline R-squared & 0.295325 & \multicolumn{2}{|c|}{ Mean dependent var } & -0.115034 \\
\hline Adjusted R-squared & 0.224858 & \multicolumn{2}{|c|}{ S.D. dependent var } & 1.255959 \\
\hline S.E. of regression & 1.105773 & \multicolumn{2}{|c|}{ Akaike info criterion } & 3.160075 \\
\hline Sum squared resid & 24.45469 & \multicolumn{2}{|c|}{ Schwarz criterion } & 3.308183 \\
\hline Log likelihood & -33.34086 & \multicolumn{2}{|c|}{ Hannan-Quinn criter. } & 3.197323 \\
\hline F-statistic & 4.190947 & \multicolumn{2}{|c|}{ Durbin-Watson stat } & 1.773130 \\
\hline Prob(F-statistic) & 0.030192 & & & \\
\hline
\end{tabular}

\section{Classical Assumptions Testing}

Classical Assumptions Testing is used to ascertain the data is unbiased, consistent, sufficient and others. Therefore, the regression estimation coefficient will become Best Linear Unbiased Estimator (BLUE) if it fulfils several classical assumptions.

The calculation results shows that linear regression equation for investment credit distribution does not violate the existing classical assumptions. This is indicated by each value that has met the criteria of Best Linear Unbiased Estimator (BLUE), the data is valid to examine model with the OLS method. The results of classic assumptions testing are below.

\section{Autocorrelation Test (Breush-Godfrey Test)}

This test assumes that main confounding factor is derived following the path-order autoregressive scheme where the equation is formed from regression equation model. The results are shown in table 3 below.

\section{Table 3. Autocorrelation Test Results}

\begin{tabular}{|l|r|l|r|}
\hline \multicolumn{2}{|l|}{ Breusch-Godfrey Serial Correlation LM Test: } & \\
\hline F-statistic & 1.421680 & Prob. F(5,16) & 0.2694 \\
\hline Obs*R-squared & 7.382665 & Prob. Chi-Square(5) & 0.1937 \\
\hline
\end{tabular}

Table 3 indicates that statistical $\mathrm{F}$ value is not significant for $\alpha 5 \%$ or $1 \%$, so it can be concluded that the data to examine the research model does not have autocorrelation symptoms.

\section{E. White Heteroskedasticity Test}

White developed a method that does not require assumptions about residual normality. Indications of heteroscedasticity is by calculating the value of $X^{2}$ where $X^{2}=n * R^{2}$. The test is if the result of calculation turns out to be $\mathrm{X}^{2}$-count $<\mathrm{X}^{2}$-Table. It means that alternative hypothesis of heteroscedasticity is rejected. The White test results are shown in table 4.

Table 4. Heteroscedasticity Test Results

\begin{tabular}{|l|r|l|r|}
\hline Heteroskedasticity Test: White & \\
\hline F-statistic & 1.395865 & Prob. F(5,18) & 0.2726 \\
\hline Obs*R-squared & 6.705697 & Prob. Chi-Square(5) & 0.2435 \\
\hline Scaled explained SS & 5.376358 & Prob. Chi-Square(5) & 0.3717 \\
\hline
\end{tabular}

Table 4 shows that that equality of unemployment level in North Maluku Province does not contain heteroscedasticity.

\section{F. Partial Correlation Testing}

Multicollinearity problems are shown by $\mathrm{R}^{2}$ and significance test through the $\mathrm{t}$ test is used to avoid multicollinearity problem in regression model. All coefficients should statistically significant with a low determination coefficient $\left(\mathrm{R}^{2}\right)$. The test result is shown in table 5 . 
Table 5. Multicollinearity Test Results

\begin{tabular}{|c|c|c|c|}
\hline & $\mathrm{D}(\mathrm{TPT})$ & $\mathrm{D}(\mathrm{INF})$ & $\mathrm{D}(\mathrm{INV})$ \\
\hline $\mathrm{D}(\mathrm{TPT})$ & 1 & 0.53177 & -0.203997 \\
\hline $\mathrm{D}$ (INF) & 0.53177 & 1 & -0.176345 \\
\hline $\mathrm{D}$ (INV) & -0.20399 & -0.176345 & 1 \\
\hline
\end{tabular}

The correlation coefficient between D (TPT) and D (INV) is -0.2039 , correlation coefficient between D (INV) and D (INF) is -0.1763 and correlation between D (TPT) and D (INF) is 0.5317 . The low correlation coefficient shows that there is no multicollinearity problem.

\section{Partial Adjustment Model (PAM)}

The partial adjustment model is shown with the formulation below.

$\mathrm{TPT}_{\mathrm{t}}=\beta_{0}+\beta_{1} \mathrm{INF}_{\mathrm{t}}+\beta_{2} \mathrm{INV}_{\mathrm{t}}+\varepsilon_{\mathrm{t}}$

The desire or unemployment balance TPT ${ }_{t}$ cannot be observed. Table 6 shows the Partial adjustment model (PAM) for TPT* ${ }_{t}$.

Table 6. Partial Adjustment Model (PAM) Test Results

\begin{tabular}{|c|c|c|c|c|}
\hline \multicolumn{5}{|c|}{ Dependent Variable: D(TPT) } \\
\hline \multicolumn{5}{|c|}{ Method: Least Squares } \\
\hline \multicolumn{5}{|c|}{ Date: $03 / 18 / 18$ Time: $07: 18$} \\
\hline \multicolumn{5}{|c|}{ Sample (adjusted): 2011Q2 2016Q4 } \\
\hline \multicolumn{5}{|c|}{ Included observations: 23 after adjustments } \\
\hline Variable & Coefficient & Std. Error & $\mathrm{t}$-Statistic & Prob. \\
\hline $\mathrm{C}$ & 2.704676 & 0.986060 & 2.742912 & 0.0129 \\
\hline $\mathrm{D}$ (INF) & 1.027595 & 0.448749 & 2.289911 & 0.0336 \\
\hline $\mathrm{D}(\mathrm{INV})$ & -0.002111 & 0.001223 & -1.727048 & 0.1004 \\
\hline TPT(-1) & 0.426096 & 0.150352 & 2.833991 & 0.0106 \\
\hline R-squared & 0.504696 & \multicolumn{2}{|c|}{ Mean dependent var } & -0.115034 \\
\hline Adjusted R-squared & 0.426490 & \multicolumn{2}{|c|}{ S.D. dependent var } & 1.255959 \\
\hline S.E. of regression & 0.951143 & \multicolumn{2}{|c|}{ Akaike info criterion } & 2.894467 \\
\hline Sum squared resid & 17.18880 & \multicolumn{2}{|c|}{ Schwarz criterion } & 3.091944 \\
\hline Log likelihood & -29.28637 & \multicolumn{2}{|c|}{ Hannan-Quinn criter. } & 2.944132 \\
\hline F-statistic & 6.453422 & \multicolumn{2}{|c|}{ Durbin-Watson stat } & 1.732641 \\
\hline Prob(F-statistic) & 0.003387 & & & \\
\hline
\end{tabular}

Source: Attachment data processed.

The positive value of inflation variable is consistent with theory and significant at $\alpha=5 \%$. The open unemployment level in previous period of TPTt-1 had a positive and significant effect on $\alpha=1 \%$. Meanwhile, private investment variable has a negative sign in accordance with theory and is significant at $\alpha=10 \%$. The adjustment coefficient is $1-0.4261=0.5739$, which means that difference of half quarterly between the desired unemployment level and the adjustment is occurred is within two months.

The long-term unemployment level is calculated by dividing the short-term unemployment level by $\delta=$ 0.5739 and without entering the TPTt-1 variable. The formulation is shown below.

$$
\mathrm{TPT}_{\mathrm{t}}=4.7128+1,7905 \mathrm{INF}_{\mathrm{t}}-0,0037 \mathrm{INV}_{\mathrm{t}}
$$

\section{Discussion of Research Results}

\section{The Effect of Inflation on Unemployment level}

Inflation is one of most important monetary events found in almost all countries in world. Omar (2004) also illustrates how the distribution between inflation and unemployment level is based on assumption that inflation is a reflection of an increase in aggregate demand. According to demand theory, demand rises will increases the price. Producers increase their production capacity by increasing labor (labor is the only input that can increase output) to fulfil the demand at high prices (inflation). As a result there is an increase in demand for labor to decrease the unemployment level.

This study result indicates that inflation level has a significant and positive effect on unemployment in North Maluku Province. It has a balance relationship in short term and long term. This means the increase in inflation level will increase unemployment. This is due to increase in inflation level caused by increase in price of fuel oil $(\mathrm{BBM})$ and government will also adjust the regional minimum wage to make private sector tends not to demand labor. In addition, higher inflation causes higher production costs and lower demand for goods and production services so the private sector will reduce its workforce. The higher inflation causes an increase in investment interest rates so the unemployment will increase along with increasing number of labor force. This study result is consistent with Algofari (2010) that inflation has no effect on unemployment in Indonesia. The higher inflation 
will not change the unemployment level in Indonesia. However, it is consistent with John Dinarno and Mark P. Moore (1999) to show positive relationship between the inflation level through GDP Deflator and unemployment level. The higher inflation in a country will affect on high unemployment level. This study result is inconsistent with theory of Philips (Nanga, 2005) that inflation has a negative relationship to unemployment.

\section{The Effect of Private Investment on Unemployment level}

Investment is a determinant of economic growth level. It drives a significant increase in output and demand for inputs that in end it will increase employment opportunities and increase people's welfare as a consequence of higher income (Makmun and Yaksin, 2003). The goods production also affect on labor demand. It increases the employment, reducing unemployment. Investments will encourage the creation of new capital to absorb new production factors, namely creating new employment opportunities to reduce unemployment (Prasojo, 2009).

This study result indicates that private investment has a significant and negative effect on unemployment in North Maluku Province. This means private investment increase will reduce the open unemployment level in North Maluku Province. This is consistent with theory of Harrod - Domar who sees the effect of investment in a longer time perspective. According to these two economists, investment expenditure (I) does not only have an effect (through a multiplier process) on aggregate demand (Z), but also on aggregate supply (S) through its effect on production capacity to reduce unemployment (Boediono, 1999). The investment invested in an area will certainly affect on unemployment in the area. The investment will expand the business, capital and labor usage will increase. Therefore, investment should reduce the unemployment.

Pratiwi (2005) said that investments that have a multiplier effect to increase welfare, as measured by higher income. This means that higher income will increase goods and services consumed. Higher demand for goods and services will increase employment opportunities to reduce the unemployment level. It is caused by absorption of workforce in investment projects. Investments have a multiplier effect to increase welfare, as measured by higher income. This means that higher income will increase the goods and services consumed. If higher demand for goods and services will increase the employment. This will reduce unemployment through absorption of workforce in investment projects.

\section{CONCLUSION}

Based on research results and discussion, the conclusions are below.

1. The inflation level affects on unemployment level in North Maluku Province, both in short and long term. This means that higher inflation will increase unemployment level in North Maluku Province.

2. Private investment has a negative and significant effect on unemployment level in North Maluku Province, both in long and short term. This means that higher private investment will reduce unemployment level in North Maluku Province.

3. The partial adjustment model show a long-term balance between the inflation, private investment and unemployment level variables in North Maluku Province.

\section{SUGGESTIONS}

1. Inflation is a macroeconomics problem. It can disrupt the economy. Government policy is needed to maintain price stability. In relation to unemployment, local government can do regulate spending and revenue (fiscal policy) to encourage community activities in production to increase inflation accompanied by job creation which in turn reduces the unemployment level.

2. The importance of investment and government expenditure in regional economic development should be concerned. The local government needs to revise expenditure allocations to more productive expenditure and revise the percentage of tax collection for industrial sector. This will affect on input costs or production capacity, thereby reducing employment opportunities.

3. Future researchers should use these research results as reference or expanding the research by adding variables such as government spending and minimum wages in order to get more complete information and improve the this study results.

\section{REFERENCES}

Amir, Amri. 2010. Pengaruh Inflasi dan Pertumbuhan Ekonomi Terhadap Pengangguran di Indonesia. Jambi: FE Universitas Jambi.

Arikunto, Suharsimi. 2006. Prosedur Penelitian, Suatu pendekatan praktek. Edisi Ketiga. Jakarta: Lembaga Penerbit FE - UI.

Arnson, Thomas Gunner, 2002 ,"Testing of the Philips Curve", 11 Desember, http://econ10.bu.edu/ec305/papers/Arnson/htm.

Arnson. 2002. Testing of the Phillips Curve . Journal of Econometrica, Vol. 32, No. 4

Awat, Napa J. 1995. Metode Statistika dan Ekonometri. Yogyakarta: Liberty, 
Dinarno, John dan Mark P. Moore. 1999. Analisa Hubungan Antara Pengangguran dan Inflasi dalam Perekonomian Terbuka dengan Menggunakan Data Panel. Jurnal Ekonomi. Economics Journal, Vol. 1, No1.

Gujarati, Damodar N. 2003. Basic Econometrics, Four Edition. New York: Mc Graw-Hill Higher Education.

Insukindro. 1990. Komponen Koefisien Regresi Jangka Panjang Model Ekonomi: Sebuah Studi Kasus Impor Barang di Indonesia. Jurnal Ekonomi dan Bisnis Indonesia, No.2, Vol.5.

Insukindro. 1993. Ekonomi Uang dan Bank; Teori dan Pengalaman di Indonesia, Edisi Pertama. Yogyakarta: BPFE-UGM.

Kauffman, Bruce E. Julie L. Hotchkiss. 1999. The Economic of Labor Markets. Fifth Edition, USA: The Dryden Press, Harcourt College Publiser.

Lansing, Kevin J, dalam Atkeson, A. and L.E. Ohanian. 2001. "Are Phillips Curves Useful for Forecasting Inflation?" FRB Minneapolis Quarterly Review (Winter). http://www.mpls.frb.org/research/qr/qr2511.html.

Lansing. 2002. Phililps Curve Examination. The Quartely of Economics Journal Vol.125 (1).

Lansing. 2002. The Qua rtely of Economics Journal Vol.125 (1), 2000.

Lipsey Richard G, Paul R Cournot, and Cristoper TS Ragan. 2007. Economics, Addiso-Wsley Publishing Company, Inc.

Mankiw, N. Gregory. 2000. Teori Makro Ekonomi: edisi keempat. Jakarta: Erlangga.

Phillips, A. W. 1958. The Relationship Between Unemployment and The Rate of Change of Money Wage Rate in the United Kingdom. Economica, New Series, Vol. 25, No. 100, pp. 283-299.

Pratiwi, Fajar. 2005. Faktor-Faktor Yang Mempengaruhi Investasi Swasta Domestik Di Provinsi Jawa Barat 1975 2003. Yogyakarta. Tesis S2. Program Pasca Sarjana UGM.

Rothbard, Murray N. 2007. What has Government Done to Our Money? (Apa yang Dilakukan Pemerintah Terhadap Uang Kita?), cet I. Jakarta: Granit,.

Rum, Moch.Alim. 2007. Analisis Faktor Penentu Pengangguran Terbuka Di Indonesia Periode 1980-2007. Jurnal Kajian Politik Dan Masalah Pembangunan Ekonomi, Vol.4, No.1, 2008.

Sriyana, Jaka. 2003. Evolusi Ekonometrik Dinamik dalam Analisis Data Time Series. Jurnal Ekonomi \& Studi Pembangunan, Vol. 4. No. 2. FE Universitas Muhammadiyah, Yogyakarta.

Sugiyono. 2008. Metode penelitian kuantitatif dan kualitatif dan R\&D. Bandung: CV. Alfabeta.

Tarigan, Robinson, 2005, Perencanaan Pembangunan Wilayah. Jakarta: PT. Bumi Aksara.

Widarjono, Agus. 2005. Ekonometrika: Teori dan Aplikasi untuk Ekonomi dan Bisnis, Edisi Pertama. Yogyakarta: Ekonisia Fakultas Ekonomi UII.

Widarjono, Agus. 2016. Ekonometrika: Pengantar dan Aplikasinya. Edisi Keempat. Yogyakarta: UPP STIM YKPN. 